\title{
Study on the Optimal International Reserve Scale in the Process of Currency Internationalization
}

\author{
Bailing Xu \\ Yunnan University Dianchi College, Kunming, Yunnan 650228, China \\ Email: xblxx2014@126.com
}

\begin{abstract}
Keywords: currency internationalization; international reserves; foreign exchange reserves
Abstract. This paper studies the changing rules of the optimal international reserve size in the view of internationalization of currency. The theoretical model indicates that the optimal scale of international reserves shows the characteristics of the first and the lower stages of the internationalization in the currency. In the early days of internationalization of currency, sufficient international reserves provide support for effective control of macro risks. At the end of the international of the currency, the international currency function of the currency began to replace the international reserves and also made the optimal scale decline. Using the two different stages of the international currency issuer data, the empirical results of this paper support the theoretical model of the conclusions. Furthermore, the paper provides a reference for expanding China's international reserve - scale management.
\end{abstract}

\section{Introduction}

As early as the golden standard period, the discussion of the size of the optimal international reserves has appeared. After the Second World War, countries generally face international payment difficulties, the international reserve adequacy problem is particularly prominent. To this end, Triffin(1960) proposed a widely accepted experience rate as a measure of the international reserve size of the appropriate standards [1]. He believes that the number of international reserves of a country should be able to pay at least 3-4 months of imports. Triffin's empirical approach establishes the proportionality of the minimum international reserve scale for postwar analysis. On the basis of this, follow-up researchers have raised the minimum scale of international reserves, such as reserves, for short-term external debt ratios, reserves to broad money supply ratios, and reserve-to-GDP ratios $[2,3]$. With the rapid recovery of the major industrial economies, the international payment contradiction can be alleviated. The adequacy of the international reserve is no longer significant, and the cost of holding international reserves is gradually emerging as the international reserves expand. Heller first considers the relationship between the cost of holding and the benefits of international reserves. He considers that the appropriate international reserve size should be the best choice for a country to hold the cost and benefit of international reserves. Between the two, the international reserves are not the most good. Heller pointed out that the role of international reserves is no longer limited to international means of payment, but a country to deal with the balance of payments imbalance protection, and therefore its purpose is to prudence as the standard. Holding international reserves can prevent a country in the event of the balance of payments deficit shocks, through the adjustment of the real economy to restore the balance through the economic pain, which is holding the proceeds of international reserves. While the cost is the opportunity cost, that is, the difference between the income of the international reserve assets and the actual investment income. Obviously, the ultimate balance appears at the marginal cost and the balance of international returns.

\section{Research on the Optimal International Reserve Scale in the Process of Currency Internationalization}

Research overview. In recent years, the optimization of the optimal size of international reserves has also introduced a utility maximization method to replace the decision variables in the original theoretical system $[4,5]$. This influential study came from Jeanne. They constructed a multi-period 
dynamic model with an open small economy as a research objective, describing the process of maximizing the behavior of the agent's wealth in the mid-span allocation process to the optimal international reserve. Although the theoretical model has a beautiful analytical solution and there is also a robust performance in the empirical, the intrinsic logic of the utility maximization model does not break through the analysis of the cost-benefit analysis framework.

Theoretical model. Considering an open country (referred to as "home country"), its economic authorities regard economic growth and macroeconomic stability as decision-making goals [6]. Assuming domestic drivers of domestic economic growth, such as domestic investment, consumption, exports, etc., the decision-making process of the national economic authorities is to promote favorable economic growth through open policy. With the increase in openness, the country can obtain more abundant external resources, such as raising the capital stock of the country and promoting the efficiency of capital allocation, and will eventually increase the output of the country $[7,8]$. But the opening will also bring risks, the risk is mainly reflected in the country facing the international impact, and its possible macroeconomic instability. To this end, through the degree of opening up as an intermediary, the country's output level $\mathrm{g}$ and the risk of opening up there is a positive relationship between. Assume that the relationship conforms to the following growth frontier curve (or "opportunity curve") form:

$$
\mathrm{g}(\sigma)=g_{0}+\alpha \sigma+\Phi m
$$

Among them, $\mathrm{g}_{0}$ is the independent growth rate of the economy completely closed, and $\alpha$ is the growth promotion effect of the opening risk. It is also assumed that the increase in the degree of internationalization of the currency will promote domestic economic growth. Currency internationalization will bring about stimulate direct exports, promote the development of financial sector and enhance the welfare of the country. But also has a certain indirect effect, such as the internationalization of capital required by the capital market can promote the effective allocation of resources to ease the information asymmetry, promote or supplement their savings, promote technological transformation, and ultimately bring economic growth; Financial market integrity is high, and through the reduction of uncertainty to promote the effective allocation of resources; currency internationalization of the currency exchange rate flexibility for the domestic monetary authorities to win a more relaxed policy space, is conducive to promoting economic growth policy implementation Wait. Assuming that the contribution of currency internationalization to economic growth is linear, the parameter $\varphi$ is the marginal contribution of internationalization of money to economic growth.

Assuming that the national economic authorities have a risk aversion preference, the utility function is:

$$
u=u_{0}(\sigma, g) \text { where } M U_{\sigma}<0, M U_{g}>0
$$

So the indifference curve convex to the origin, the specific utility function for the logarithmic quasi-linear form:

$$
U_{c}(\sigma, g)=g * \exp (-c \sigma), c>0
$$

Indicates the degree of risk aversion. According to the form of the utility function, the indifference curve of the convexity feature can be obtained as follows:

$$
g(\sigma)=u^{0} e^{c \sigma}
$$

With the risk of opening to the outside world as the decision variable and the optimal economic growth $\mathrm{g}$ as the target variable, the favorable level of open risk under the optimal growth condition is as follows:

The degree of openness of capital projects and the fragility of the domestic financial system have a direct impact on the risk. The higher the degree of openness of capital projects, the greater the risk of opening up to the outside world; and the improvement of the financial system in the country will be reduced due to the opening of capital projects. At the same time, the control of the risk of international reserves held by the country is also important. Thus, the risk of opening the external 
level of $\sigma^{*}$ is decomposed into three policy variables, including the degree of openness of capital items a, the fragility of the financial system $b$, and the scale of foreign exchange reserves $r$. Variables $a, b$, rare integers, where the greater the value of a greater represents the higher degree of openness; $b$ the greater the greater the degree of fragility of the financial system; the greater the greater the relative size of the country's international reserves. The increase in the degree of openness of capital projects in China will lead to more likely to face the impact [6] of the international financial system, the risk will rise. The simple form of constructing the internationalization of foreign currency and the impact of foreign exchange reserves on opening to the outside world is as follows:

$$
\sigma=\frac{\delta_{m}}{\theta_{r}+\gamma_{m}}
$$

The specific conditions are:

$$
\begin{gathered}
\sigma^{*}=A-\frac{\phi}{\alpha} m=\frac{\delta_{m}}{\theta_{r}+\gamma_{m}} \\
r^{*}=\frac{1}{\theta}\left[\frac{\delta_{m}}{A-\frac{\phi}{\alpha} m}-\gamma_{m}\right]
\end{gathered}
$$

It shows that there are three kinds of conduction mechanisms for the effect of the degree of internationalization of money on the optimal international reserve size $\mathrm{r}$ *

The influence of the internationalization degree of the currency on the optimal international reserve is not the same as the influence of the three mechanisms, and is combined in a non-linear form. We can't see directly with the increase in $\mathrm{m}$, the optimal international reserve $\mathrm{r}$ * changes. To this end, for the above formula (7) to construct a comparative static analysis:

$$
m^{*}=\frac{\alpha}{\phi}\left[A \pm \sqrt{\frac{\delta A}{\gamma}}\right]
$$

According to the model setting, all the parameters in the above formula are positive numbers, so the larger of the two roots of $\mathrm{m} *$ is always greater than zero. While the other root symbol depends on the relationship between the parameters.

\section{Empirical analysis}

\section{Variable selection and data sources}

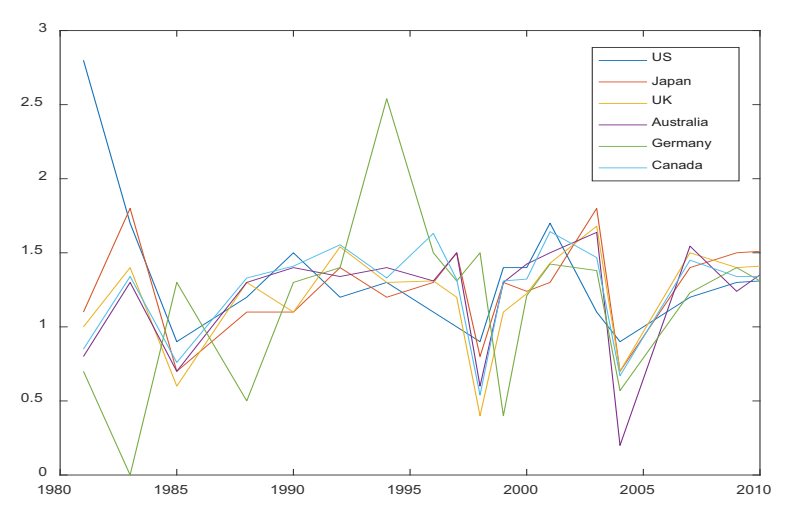

Figure 1.National reserve of developed country

The choice of time span of sample data: the first group of selected 1981-2010, mainly taking into account the initial collapse of the Bretton Woods system. The international monetary system is still in the unstable stage. Into the 80 's, the floating exchange rate system into a relatively stable period, the first group of countries, international reserve size also tends to be stable. The second group of selected 1990-2010, which mainly takes into account the economic globalization and the financial 
liberalization in the period of rapid advance. The second group of countries is brought about by the international opportunity of currency.

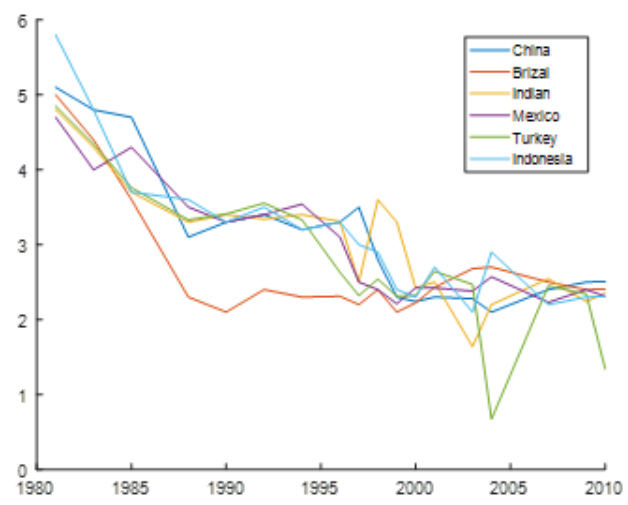

Figure 2.National reserve of developing country

Model setting and estimation method and measurement results. According to the variable selection scheme, the explanatory variable is set as the ratio of international reserves to M2. The explanatory variables are capital market openness and exchange rate stability index. The control variables include the GDP growth rate, import and GDP ratio, short term external debt the ratio of GDP, the ratio of foreign direct investment to GDP, and the ratio of short-term securities investment to GDP. The specific basis for the regression equation is as follows:

$$
R T M_{a}=\alpha_{0}+\alpha_{1} \operatorname{KAOPEN}_{a}+\alpha_{2} E R S+\beta_{1} i_{11}+\varepsilon_{11}
$$

Table 1.Some regression results

\begin{tabular}{|c|c|c|c|c|c|c|}
\hline \multirow{2}{*}{} & \multicolumn{3}{|c|}{ International currency issuer } & \multicolumn{2}{c|}{ Potential international currency issuer } \\
\cline { 2 - 7 } & FGLS & SGMM1 & SGMM2 & FGLS & SGMM1 & SGMM2 \\
\hline RTM(-1) & & 0.753 & 0.636 & & 0.232 & 0.288 \\
\hline RTM(-2) & & 0.097 & & & 0.103 & \\
\hline ERS & 0.000 & 0.015 & 0.011 & 0.049 & 0.055 & 0.034 \\
\hline KAOPEN & -0.032 & -0.019 & -0.013 & -0.030 & -0.015 & -0.014 \\
\hline itg & 0.009 & 0.038 & 0.029 & 0.335 & 0.653 & 0.612 \\
\hline ftg & -0.052 & -0.047 & -0.036 & -1.954 & -1.394 & -1.319 \\
\hline etg & -0.014 & -0.018 & 0.004 & 0.110 & 0.173 & 0.149 \\
\hline dtg & -0.000 & -0.000 & -0.001 & -0.001 & -0.002 & -0.002 \\
\hline
\end{tabular}

The international reserves of the two groups reflect different variables. The first group of short-term securities investment in the country has a significant proportion of GDP, and the coefficient is positive, while the other control variables [6,7] are not significant. It is pointed out that the important purpose of the international currency issuer's holding of international reserves includes the impact of short-term capital flows, which is related to its fully open capital market, and the capital flows in the form of current account balance and FDI have no effect on international reserves. Changes in the size of the economy have no effect on international reserves. The second group of countries' share of GDP as well as the proportion of FDI to GDP is significant in all models, indicating that these developing countries or emerging market economies hold international reserves primarily for the balance of payments under the current account and International direct investment to provide support. Short-term securities investment in GDP is not significant, can be interpreted as these countries, the low degree of openness of the capital market, which is not the main use of international reserves. At the same time, the rate of economic growth of the second group of countries has a certain impact on the international reserves, showing a slow growth of the national preference for the phenomenon of reserves. The characteristics of the two sets of control variables are also directly related to the different stages of development of the two groups of countries. 


\section{Summary}

The conclusion of this paper provides some reference value for understanding the relationship between China's international reserve management and RMB internationalization strategy. The author holds that the purpose of international reserves is diversified, but it is mainly based on the motive of prevention. Especially when faced with the risk of internationalization of currency, the international reserves are of great significance to the prevention and control of risks. In addition, it is obvious that the deficiency is only from the perspective of transaction purpose or cost-benefit analysis. To this end, to discuss the optimal scale of China's international reserves should be based on the China's reality and the historical process of the RMB internationalization of a comprehensive study. China's "excessive" international reserves are the inevitable outcome of the process of economic transition. Though the domestic market reform has not yet been fully completed, the domestic financial system is still need to improve the situation urgently. At the same time, "excessive" international reserves are also the result of our reserve system.

\section{References}

[1] Guoping Z, Lizhen L, Weiwei Z. Optimal International Reserve Scale In the Process of Currency Internationalization[J]. Studies of International Finance, 2014, 3: 003.

[2] Lee J W. Will the Renminbi Emerge as an International Reserve Currency?[J]. The World Economy, 2014, 37(1): 42-62.

[3] Zhang Z. The size of foreign exchange reserves and local currency internationalization: cross-country evidence[J]. The Singapore Economic Review, 2015: 1550081.

[4] Song X. Determinants of international currency competition in the international debt securities market: An empirical analysis based on dynamic panel data model[J]. BioTechnology: An Indian Journal, 2014, 10(15).

[5] Endres A M. Doctrinal Developments in International Money: The Question of Currency Internationalisation from Bretton-Woods to the 1970's[J]. 2016.

[6] Zhang Z, Makin.AJ, Bai Q. Yen internationalization and Japan's international reserves[J]. Economic Modelling, 2016, 52: 452-466.

[7] Liao S, McDowell D. No reservations: International order and demand for the renminbi as a reserve currency[J]. International Studies Quarterly, 2016: sqv020.

[8] Zhang L, Tao K. The Economics of RMB Internationalization[J]. Asian Economic Papers, 2016. 